Volume 3 Nomor 1, Februari 2018, halaman 23-32

\title{
PENGARUH STRATEGI PEMBELAJARAN SISIPAN HUMOR TERHADAP HASIL BELAJAR MATEMATIKA
}

\section{THE INFLUENCE OF THE INSERTION OF HUMOR LEARNING'S STRATEGY TO THE MATHEMATICS ACHIEVEMENT}

\author{
Mochammad Taufan \\ Universitas Wiralodra, Jln. Ir. H. Djuanda KM.3 Singaraja Indramayu 45213, \\ mochammad.taufan89@gmail.com
}

\begin{abstract}
ABSTRAK
Penelitian ini bertujuan untuk mengetahui hasil belajar matematika siswa yang pembelajarannya menggunakan strategi pembelajaran sisipan humor; untuk mengetahui hasil belajar matematika siswa yang pembelajarannya tidak menggunakan strategi pembelajaran sisipan humor, untuk mengetahui pengaruh strategi pembelajaran sisipan humor terhadap hasil belajar matematika. Metode penelitian yang digunakan dalam penelitian ini adalah metode eksperimen. Populasi dalam penelitian ini adalah seluruh siswa kelas XI SMK Negeri 1 Balongan dan dipilih dua kelas secara acak sebagai sampel. Kelas XI TKJ 1 sebagai kelas eksperimen yang pembelajarannya menggunakan strategi pembelajaran sisipan humor dan kelas XI TKJ 2 sebagai kelas kontrol yang pembelajarannya tidak menggunakan sisipan humor. Instrumen yang digunakan dalam penelitian ini adalah tes. Berdasarkan hasil analisis, dapat disimpulkan bahwa terdapat pengaruh strategi pembelajaran sisipan humor terhadap hasil belajar matematika.
\end{abstract}

Kata kunci: Strategi Pembelajaran, Sisipan Humor, Hasil Belajar Matematika

\begin{abstract}
The purpose of this research are to know the math achievement of students who use the insertion of humor learning's strategy; to know the math achievement of students who not use the insertion of humor learning's strategy, to know the effect of the insertion of humor to math achievement. This research used the experiment method. The population of this research is whole students grade is XI at SMK Negeri 1 Balongan and taken two classes at random according to the class as a sample. Class XI TKJ 1 as the experiment class that use the insertion of humor learning 's strategy and class XI TKJ 2 as the control class that not use the insertion of humor learning's strategy. Instrumens that used in this research is test. Based on the analysis result, it could be concluded that any effect the insertion of humor learning's strategy to math achievement.
\end{abstract}

Keywords: Learning's Strategy, Insertion of Humor, Mathematics Achievement

How to Cite: Taufan, M. (2018). Pengaruh Strategi Pembelajaran Sisipan Humor Terhadap Hasil Belajar Matematika. Mathline: Jurnal Matematika dan Pendidikan Matematika, Vol.3, No.1, 23-32. 


\section{PENDAHULUAN}

Pendidikan matematika merupakan salah satu aspek kehidupan yang memegang peranan penting dalam upaya membina dan membentuk manusia berkualitas. Pada dasarnya setiap hari manusia selalu terlibat dengan matematika, mulai dari bentuknya yang sederhana dan rutin sampai pada bentuknya yang sangat kompleks. Salah satu sarana penunjang untuk membentuk manusia berkualitas adalah dengan melaksanakan pembelajaran matematika di sekolah.

Pembelajaran matematika di sekolah merupakan sarana untuk membentuk pola pikir manusia yang jelas, kritis, kreatif, sistematis, dan logis. Pembelajaran matematika bertujuan untuk mempermudah menyelesaikan berbagai masalah dalam kehidupan seharihari, mulai dari masalah yang sederhana hingga masalah yang sangat kompleks. Hal ini menyebabkan matematika dipelajari oleh semua siswa dari jenjang dasar (SD) sampai perguruan tinggi.

Oleh karena itu, seluruh siswa dianjurkan untuk senang, menguasai, dan memahami matematika dengan baik. Untuk menguasai dan memahami matematika dengan baik, dibutuhkan minat belajar matematika yang tinggi dari setiap siswa. Memahami matematika tidak hanya ditunjukkan dengan hasil belajar yang baik, tapi juga ditunjukkan dengan kemampuan komunikasi siswa dalam pembelajaran matematika.

Tetapi realita yang ada menunjukkan bahwa banyak siswa yang tidak menyukai pelajaran matematika karena menganggap matematika sebagai ilmu yang paling sulit untuk dipelajari, sehingga menyebabkan rendahnya hasil belajar matematika siswa di sekolah. Hasil penelitian Herman Nirwana dikutip Darmansyah (2010) mengungkapkan bahwa, "Di antara empat pelajaran yang diteliti (fisika, kimia, bahasa inggris, dan matematika), ternyata pada pelajaran matematika paling banyak siswa absen dan meninggalkan kelas sebelum pelajaran selesai". Hasil penelitian itu menunjukkan bahwa mata pelajaran matematika termasuk salah satu mata pelajaran yang kurang disukai siswa.

Tanpa disadari, pembelajaran matematika di sekolah bukan membuat siswa riang, kreatif dan terbebaskan, tetapi justru menjadi momok yang sangat menakutkan. Ketidakgairahan panjang dalam interaksi belajar-mengajar akan terjadi setiap jam pelajaran berlangsung. Kelas tidak lagi kondusif, akan dialami kegaduhan, kelas lesu, tidak ada timbal balik positif dari siswa akibat komunikasi guru dan siswa yang tidak dibingkai dalam suasana kebersamaan. Hal inilah yang menyebabkan rendahnya hasil belajar matematika siswa di sekolah. Hal tersebut diperkuat oleh Tamurih (2016) yang menyatakan bahwa, "Dari ulangan harian dan evaluasi tiap bab serta ulangan tiap semester 
yang telah dilaksanakan, menunjukkan rata-rata nilai matematika masih di bawah KKM yang sudah ditetapkan. Hasil belajar matematika ini relatif lebih rendah jika dibandingkan dengan mata pelajaran lainnya yang diberikan di sekolah".

Secara umum ada dua faktor yang mempengaruhi tinggi rendahnya hasil belajar matematika siswa, yaitu : (a) Faktor Internal, yaitu faktor yang berasal dari dalam diri siswa itu sendiri. Contoh : kecerdasan, bakat, minat, perhatian, motivasi, dan cara belajar; (b) Faktor Eksternal, yaitu faktor yang berasal dari luar. Contoh : lingkungan keluarga, pergaulan, lingkungan sekolah dan sarana pendukung belajar.

Di antara beberapa faktor di atas, yang paling banyak ditemui adalah rendahnya minat belajar matematika siswa. Hal ini diakibatkan karena siswa menganggap pelajaran matematika itu sangat sulit. Rendahnya minat belajar ini bisa terlihat dalam proses pembelajaran di kelas dan hasil belajar mereka. Siswa lalai dalam melaksanakan tugastugas kompetensi yang diberikan guru, terkesan apa adanya, atau menunaikan tugas pelajaran dengan cara praktis, yakni mencontek milik teman kelas lain. Siswa sudah kurang termotivasi untuk berfikir sendiri, yang penting praktis dan instan.

Langkah pertama untuk meningkatkan hasil belajar matematika siswa yaitu membangkitkan minat belajar matematika siswa. Ada banyak cara membangkitkan minat belajar siswa salah satunya adalah dengan menciptakan suasana belajar yang menyenangkan. Jadi, cara membangkitkan minat belajar siswa terletak pada kemampuan guru merancang dan menerapkan strategi pembelajaran yang menyenangkan. Menurut Ahmadi (2011), "Strategi pembelajaran merupakan cara-cara yang akan dipilih dan digunakan oleh seorang pengajar untuk menyampaikan materi pelajaran sehingga akan memudahkan peserta didik mencapai tujuan pembelajaran yang diharapkan akan dikuasainya di akhir kegiatan belajarnya". Hal ini sejalan dengan pendapat Majid (2013) yang menyatakan bahwa, "Strategi pembelajaran merupakan suatu rencana tindakan (rangkaian kegiatan) yang termasuk penggunaan metode dan pemanfaatan berbagai sumber daya atau kekuatan dalam pembelajaran". Jadi, dapat disimpulkan bahwa strategi pembelajaran adalah suatu cara yang dilakukan oleh seorang guru dalam kegiatan pembelajaran untuk mencapai tujuan pembelajaran.

Ada beberapa strategi pembelajaran yang diharapkan mampu meningkatkan kemampuan komunikasi matematis siswa, salah satunya yaitu menggunakan strategi pembelajaran sisipan humor. Memberikan sisipan humor dalam pembelajaran diharapkan mampu menciptakan suasana belajar yang menarik dan menyenangkan bagi siswa. Pembelajaran yang menarik dan menyenangkan akan dapat meningkatkan pemahaman, 
mempertajam daya ingat, dan memberi peluang kepada siswa untuk memfungsikan otak memori dan otak berpikirnya secara optimal. Hal ini diperkuat oleh pendapat Loomas dan Kolberg yang dikutip Darmansyah (2010), menyatakan bahwa "sifat humoris guru dan kemampuan guru menggunakan berbagai sumber untuk menciptakan suasana yang humoris akan membuat siswa lebih kreatif".

Salah satu faktor yang menentukan berhasil tidaknya suatu proses pembelajaran adalah cara guru mengajar. Untuk memperoleh hasil belajar yang maksimal, guru harus mampu meningkatkan motivasi belajar siswa dengan cara menciptakan suasana pembelajaran yang menyenangkan. Menurut Darmansyah (2010), "Sisipan dalam pembelajaran adalah cara komunikasi dan interaksi guru dengan siswa dalam proses pembelajaran agar menciptakan suasana belajar yang menyenangkan". Ada berbagai cara untuk menciptakan suasana pembelajaran yang menyenangkan, salah satunya menggunakan sisipan humor.

Menurut Sheinowizt (Darmansyah, 2010), "Humor adalah kualitas yang bersifat lucu dari seseorang yang menggelikan dan menghibur". Humor dapat juga diartikan sebagai kemampuan untuk menerima, menikmati, dan menampilkan sesuatu yang lucu, ganjil/aneh yang bersifat menghibur. Menurut Darmansyah (2010), "Sisipan humor dalam pembelajaran adalah komunikasi yang dilakukan guru dengan menggunakan sisipan katakata, bahasa, dan gambar yang mampu menggelitik siswa untuk tertawa”. Sisipan humor dapat menjadikan komunikasl antara guru dan murid menjadi lebih mudah dan menarik karena humor mampu memfasilitasi seseorang untuk mengungkapkan kata-kata yang tidak mudah diucapkan. Hal ini diperkuat Darmansyah (2010) yang menyatakan bahwa, "humor seorang guru mendorong anak-anak untuk selalu ceria dan gembira serta tidak akan lekas merasa bosan atau lelah". Berdasarkan penjelasan di atas, dapat disimpulkan bahwa sisipan humor dalam pembelajaran adalah suatu strategi pengorganisasian pembelajaran untuk menciptakan suasana belajar yang menyenangkan.

Sheinowitz (Darmansyah, 2010) membagi rancangan humor untuk pembelajaran dalam dua jenis, yaitu:

\section{Planned Humor}

Planned humor adalah humor yang direncanakan untuk pembelajaran dengan menggunakan berbagai sumber belajar yang memungkinkan terpicunya keinginan tertawa pada peserta didik. Beberapa bentuk planned humor diantaranya, yaitu: karikatur humor, cerita humor, dan desain humor khusus dalam bahan ajar. 


\section{Unplanned Humor}

Unplanned humor adalah humor yang tidak direncanakan. Humor ini bersifat spontanitas dan dipicu oleh berbagai aktivitas dalam pembelajaran.

Penggunaan jenis humor yang dalam pembelajaran dapat menciptakan suasana pembelajaran yang menyenangkan, sehingga dapat menghilangkan kejenuhan dalam pembelajaran. Oleh karena itu, pemilihan jenis humor yang tepat dapat membangkitkan kembali motivasi belajar siswa dalam proses pembelajaran. Sisipan humor yang digunakan dalam penelitian ini adalah cerita humor singkat, cerita humor tentang matematika dan teknik pemahaman materi matematika melalui humor.

Seorang guru guru perlu merancang waktu yang tepat untuk menyisipkan humor. Jika menggunakan humor pada waktu yang tidak tepat, bisa menimbulkan masalah. Suasana kelas menjadi kurang kondusif, materi pembelajaran tidak tersampaikan dengan baik, tujuan pembelajaran tidak tercapai, dan tentu saja mengganggu kelas lain yang terdekat. Oleh karena itu, penentuan waktu yang tepat untuk menyampaikan humor sangat penting agar sisipan humor yang digunakan lebih efektif.

Seorang guru harus memilih suatu cara untuk menyisipkan humor dalam pembelajaran, agar penyampaiannya dapat disesuaikan dengan jenis humor yang digunakan dan situasi kelas. Waktu yang tepat untuk menggunakan sisipan humor dalam pembelajaran dibagi menjadi tiga, yaitu: (a) pada pertemuan awal; (b) saat jeda strategis; (c) pada akhir pembelajaran. Agar humor yang digunakan efektif, langkah awal yang harus dilakukan guru pada pertemuan pertama adalah mencitrakan dirinya sebagai orang yang humoris, tidak pemarah, mudah diajak bicara, tidak mudah tersinggung, mau mendengar dan menerima saran dari siswa. Pembelajaran akan lebih efektif, apabila guru mampu menyisipkan humor pada waktu yang tepat, yaitu pada saat jeda strategis. "Jeda strategis adalah istirahat sejenak (kurang lebih 3-5 menit) dalam proses pembelajaran setelah pembelajaran berjalan selama periode 25-30 menit" (Darmansyah, 2010).

Langkah berikutnya adalah menutup pembelajaran dengan suasana menyenangkan. Mengakhiri pembelajaran dengan suasana senang membuat siswa tidak memiliki beban dalam menghadapi pertemuan berikutnya. Bahkan dalam kondisi tertentu, siswa menjadi sangat antusias dan menunggu pertemuan berikutnya dengan penuh harapan. Penggunaan sisipan humor dalam pembelajaran pada waktu yang tepat, dapat menimbulkan interaksi yang baik antara guru dan siswa, sehingga tujuan pembelajaran dapat tercapai dengan baik. 
Menurut Darmansyah (2010), "Secara garis besar ada empat manfaat humor dalam pembelajaran yaitu: (a) membangun hubungan dan meningkatkan komunikasi antara guru dan peserta didik; (b) mengurangi stres; (c) membuat pelajaran menjadi menarik; dan (d) meningkatkan daya ingat suatu materi pelajaran”. Penggunaan humor dalam pembelajaran sangat membantu siswa meningkatkan motivasi dan hasil belajar, terutama saat mereka sedang mengalami penurunan konsentrasi, jenuh, dan bosan dalam belajar. Hal ini sesuai dengan pendapat Treft dan Blakeslee (Darmansyah, 2010), "Humor adalah suatu cara terbaik membuat materi pelajaran yang membosankan menjadi lebih menarik bagi siswa dan para guru. Tentu saja dalam pelajaran yang menarik akan membuahkan hasil belajar yang lebih baik". Bahkan humor dapat meningkatkan daya ingat dan kemampuan memahami pelajaran yang abstrak sekalipun. Jadi, pembelajaran matematika yang menggunakan strategi pembelajaran sisipan humor diharapkan mampu meningkatkan hasil belajar matematika siswa.

Tujuan penelitian ini adalah untuk mengetahui: hasil belajar matematika siswa yang pembelajarannya menggunakan strategi pembelajaran sisipan humor; hasil belajar matematika siswa yang pembelajarannya tidak menggunakan strategi pembelajaran sisipan humor; pengaruh strategi pembelajaran sisipan humor terhadap hasil belajar matematika.

\section{METODE PENELITIAN}

Metode yang digunakan dalam penelitian ini adalah metode eksperimen. Menurut Riduwan (2008), "Penelitian eksperimen adalah suatu penelitian yang berusaha mencari pengaruh variabel tertentu terhadap variabel yang lain dalam kondisi yang terkontrol secara ketat". Tujuan penggunaan metode eksperimen dalam penelitian ini adalah untuk mengetahui sejauh mana berpengaruhnya dua perlakuan yang berbeda dan untuk mengetahui perlakuan yang lebih baik terhadap hasil belajar matematika siswa. Hal ini sesuai dengan pendapat Nazir (2005) yang menyatakan bahwa, "Tujuan dari penelitian eksperimen adalah untuk menyelidiki ada tidaknya hubungan sebab akibat serta seberapa besar hubungan sebab akibat tersebut dengan cara memberikan perlakuan-perlakuan tertentu pada beberapa kelompok eksperimen dan menyediakan kontrol untuk perbandingan". Penelitian ini menggunakan dua perlakuan, yaitu kelas eksperimen adalah kelas yang pembelajarannya menggunakan strategi pembelajaran sisipan humor, sedangkan kelas kontrol adalah kelas yang pembelajarannya tidak menggunakan strategi pembelajaran sisipan humor. 
Desain penelitian yang digunakan adalah:

$\mathrm{R}: X_{1} \mathrm{O}$

$\mathrm{R}: X_{2} \mathrm{O}$

Keterangan :

R : Simple Random Sampling untuk menentukan sampel

$X_{1} \quad$ : Perlakuan untuk kelas eksperimen

$X_{2} \quad$ : Perlakuan untuk kelas kontrol

O : Tes Akhir

Populasi dalam penelitian ini adalah seluruh siswa kelas XI SMK N 1 Balongan dan dipilih dua kelas sebagai sampel dengan menggunakan teknik Simple Random Sampling. Data diperoleh dari hasil tes instrumen hasil belajar matematika. Instrumen yang digunakan telah diuji coba dengan kriteria validitas $r \geq 0,79$ dan kriteria reliabilitas $r_{11}=0,61$. Teknik analisi data menggunakan uji parametrik (Uji-t). Perhitungan statistik menggunakan aplikasi Microsoft Excel.

\section{HASIL DAN PEMBAHASAN}

Berikut adalah data hasil penelitian.

\section{Tabel 1 Deskripsi Data Hasil Penelitian}

\begin{tabular}{cccc}
\hline Kelas & $\boldsymbol{\mu}$ & $\mathbf{S}$ & $\boldsymbol{s}^{\mathbf{2}}$ \\
\hline Eksperimen & 64,68 & 12,13 & 147,1 \\
Kontrol & 59,95 & 12,95 & 167,61
\end{tabular}

Berdasarkan data di atas, menunjukkan bahwa pada kelas eksperimen diperoleh nilai rata-rata sebesar 64,68 dan standar deviasi sebesar 12,13 , sedangakan pada kelas kontrol diperoleh nilai rata-rata sebesar 59,95 dan standar deviasi 12,95. Hal ini menunjukkan bahwa nilai rata-rata hasil belajar kelas eksperimen lebih baik dari kelas kontrol dan sebaran data pada kelas kontrol lebih variatif dari rata-ratanya dibandingkan dengan data kelas eksperimen.

Untuk melihat rata-rata perbedaan antara kelas eksperimen dan kelas kontrol, data yang diperoleh terlebih dahulu dilakukan uji normalitas dan uji homogenitas. Data hasil uji normalitas dan uji homogenitas dapat dilihat pada tabel berikut. 
Tabel 2 Uji Normalitas

\begin{tabular}{cccc}
\hline Kelas & $\boldsymbol{X}^{2}$ hitung & $\boldsymbol{X}^{2}$ tabel & Ket. \\
\hline Eksperimen & 3,03 & \multirow{2}{*}{7,81} & Normal \\
Kontrol & 5,25 & & Normal \\
\hline
\end{tabular}

Berdasarkan data di atas, menunjukkan bahwa pada kelas eksperimen dan kelas kontrol, data yang diperoleh berdistribusi normal. Selanjutnya, dilakukan uji homogenitas sebagai berikut.

\section{Tabel 3 Uji Homogenitas}

\begin{tabular}{ccc}
\hline $\boldsymbol{F}_{\text {hitung }}$ & $\boldsymbol{F}_{\text {tabel }}$ & Ket. \\
\hline 1,14 & 1,88 & Homogen
\end{tabular}

Berdasarkan data di atas, diperoleh bahwa pada kelas eksperimen dan kelas kontrol menunjukkan data homogen.

Tabel 4 Uji-t

\begin{tabular}{cccc}
\hline Kelas & $\boldsymbol{S}$ & $\boldsymbol{t}_{\text {hitung }}$ & $\boldsymbol{t}_{\text {tabel }}$ \\
\hline $\begin{array}{c}\text { Eksperimen } \\
\text { Kontrol }\end{array}$ & 7,92 & 8,17 & 1,67 \\
\hline
\end{tabular}

Berdasarkan hasil penelitian dan analisis data yang dilakukan dengan taraf signifikasi $(\alpha)=0,05$ dan derajat kebebasan $(\mathrm{db})=56$ diperoleh $t_{\text {hitung }}=8,17$ dan $t_{\text {tabel }}=1,67$. Karena $t_{\text {hitung }}>t_{\text {tabel }}$, maka Ho ditolak. Artinya terdapat pengaruh strategi pembelajaran sisipan humor terhadap hasil belajar matematika.

Hasil penelitian menunjukkan bahwa terdapat pengaruh strategi pembelajaran sisipan humor terhadap hasil belajar matematika. Hal ini ditunjukkan dengan nilai rata-rata hasil belajar siswa yang pembelajarannya menggunakan strategi pembelajaran sisipan humor lebih baik dari nilai rata-rata siswa yang pembelajarannya tidak menggunakan strategi pembelajaran sisipan humor. Hasil tersebut sesuai dengan pendapat Treft dan Blakeslee (Darmansyah, 2010), "Humor adalah suatu cara terbaik membuat materi pelajaran yang membosankan menjadi lebih menarik bagi siswa dan para guru. Tentu saja dalam pelajaran yang menarik akan membuahkan hasil belajar yang lebih baik". Hasil penelitian tersebut mendukung hasil penelitian Wulandari \& Duryati (2014) bahwa "Strategi mengajar menggunakan humor terbukti efektif memberikan pengaruh terhadap 
peningkatan prestasi belajar siswa". Hal tersebut sejalan dengan hasil penelitian Darmansyah (2009), bahwa "Strategi pembelajaran menggunakan sisipan humor efektif dalam meningkatkan hasil belajar matematika".

Kelebihan dalam menerapkan strategi pembelajaran sisipan humor dalam proses pembelajaran adalah mampu menciptakan suasana pembelajaran yang menarik dan menyenangkan sehingga siswa tidak merasa bosan atau jenuh selama proses pembelajaran di kelas berlangsung. Hal ini sesuai dengan pendapat Darmansyah (2010) yang menyatakan bahwa, "humor seorang guru mendorong anak-anak untuk selalu ceria dan gembira serta tidak akan lekas merasa bosan atau lelah".

Pembelajaran yang menarik dan menyenangkan dapat membangun interaksi dan komunikasi yang baik antara siswa dan guru. Salah satu faktor yang menentukan berhasilnya suatu proses pembelajaran adalah interaksi dan komunikasi yang baik antara siswa dan guru. Menurut Hill (Darmansyah, 2010), "Sebagian besar kegagalan bukan karena ketidakmampuan dalam bekerja, tetapi karena kurang berhasilnya dalam membangun hubungan dan komunikasi”. Komunikasi antara guru dan siswa memegang peranan penting dalam pembelajaran matematika. Hal tersebut sesuai dengan pendapat Mahardika (2014) yang menyatakan bahwa, "Komunikasi dalam matematika menolong guru memahami pemahaman siswa dalam menginterpretasi dan mengekspresikan pemahamannya tentang konsep dan proses matematika yang mereka pelajari”. Humor adalah salah satu cara yang paling efektif untuk membangun komunikasi antara guru dan siswa. Hal tersebut mendukung oleh pendapat Hickman dan Crossland (Makenwa, et al., 2011) menyatakan bahwa, "Prestasi belajar siswa dapat berubah-ubah, tetapi setelah diterapkan humor dalam proses belajar, terdapat adanya hubungan positif antara guru yang menggunakan humor dan prestasi akademis bahkan mengikuti siswa ke perguruan tinggi”. Pendapat tersebut sejalan dengan pendapat Darmansyah (2010) yang menyatakan bahwa, "humor seorang guru mendorong anak-anak untuk selalu ceria dan gembira serta tidak akan lekas merasa bosan atau lelah". Hal ini menyebabkan siswa tidak takut atau malu untuk bertanya ketika terdapat materi yang belum dipahami sehingga terjadi proses komunikasi yang baik antara guru dan siswa. Selain itu, siswa yang pembelajarnnya menggunakan strategi pembelajaran sisipan humor memiliki daya ingat yang lebih baik dari siswa yang pembelajarnnya tidak menggunakan strategi pembelajaran sisipan humor . Hal ini sejalan dengan pendapat Korobkin (Darmansyah, 2010), "Informasi di ruang kelas akan lebih mudah diingat apabila ditampilkan dalam bentuk-bentuk yang bersifat humoris". Berdasarkan penjelasan di atas, penerapan strategi pembelajaran sisipan humor 
dalam pembelajaran matematika dapat membuat suasana pembelajaran yang aktif dan menyenangkan, dan dapat meningkatkan daya ingat sehingga siswa dapat memperoleh hasil belajar matematika yang baik Jadi, terdapat pengaruh strategi pembelajaran sisipan humor terhadap hasil belajar matematika.

\section{KESIMPULAN}

Berdasarkan uraian di atas, maka dapat disimpulkan bahwa: nilai rata-rata hasil belajar kelas eksperimen sebesar 64,68 dari skor maksimal ideal 90 dengan standar deviasi sebesar 12,13; nilai rata-rata hasil belajar kelas kontrol sebesar 59,95 dari skor maksimal ideal 90 dengan standar deviasi sebesar 12,95; terdapat pengaruh strategi pembelajaran sisipan humor terhadap hasil belajar matematika.

\section{DAFTAR PUSTAKA}

Ahmadi, I. K. (2011). Strategi pembelajaran berorientasi KTSP. Jakarta. Prestasi Pustaka. Darmansyah. (2009). Pembelajaran Menggunakan Sisipan Humor dalam Mata Pelajaran Matematika. Jurnal Kependidikan, Vol.10, No.1, Juni 2009, 31-41.

------------. (2010). Strategi Pembelajaran Menyenangkan dengan Humor. Jakarta: Bumi Aksara.

Mahardika, D. P. (2014). Peranan Komputer untuk Meningkatkan Kemampuan Komunikasi Matematik Siswa Menengah Pertama. Prosiding, 18 (1), 136-140.

Majid, A. (2015). Strategi pembelajaran. Bandung: Remaja.

Makenwa, L. N., Role, E., \& Genga J. A. (2011). Teacher's Use of Humor in Teaching and Student's Rating of Their Effectiveness. International Journal of Education, Vol.3, No.2, 1-17.

Nazir, M. (2005). Metode penelitian. Bogor: Ghalia Indonesia.

Riduwan. (2008). Belajar Mudah Penelitian untuk Guru - Karyawan dan Peneliti Pemula. Bandung: Alfabeta.

Tamurih. (2016). Sudut-Sudut Berelasi dengan Grafik Fungsi Sinus dan Cosinus. Mathline: Jurnal Matematika dan Pendidikan Matematika, Vol.1, No.1, 53-62.

Wulandari, N \& Duryati. (2014). Efektivitas Strategi Mengajar Menggunakan Humor dalam Meningkatkan Prestasi Siswa pada Pelajaran Matematika. Jurnal RAP UNP, Vol.5, No.1, 53-61. 